\title{
DETERMINANTS OF INTEREST IN SAVING FOR STUDENTS IN ISLAMIC BANKING
}

\author{
${ }^{123}$ Wahyuning Murniati, Deni Juliasari, Nani Hanifah \\ Departement of Accountinng, STIE Widya Gama Lumajang ${ }^{12}$ \\ IAIN Fattahul Muluk Papua \\ Email: wahyuning123@gmail.com
}

\section{A R T I C L E I N F O}

Date of entry:

16 Januari 2020

Revision Date:

18 February 2020

Date Received:

7June 2020

\begin{abstract}
A B S T R A C T
Saving money is the way to regulate our finance effectively. Bank is one of the media that is considered quite effective for this activity. The development of Islamic economic make sharia banking practices increase in an innovative way. Various sharia bank products have become a choice for saving activity. The same thing happen for student. Although the interest to save is still lacking, but the use of sharia bank products is quite beneficial for their future. The purpose of this study is to analyze the factors that influence student interest in saving on Islamic banking. Multiple linear regression is an analysis technique with hypothesis testing to support its conclusions. With a coefficient of determination of $61.2 \%$, the results of the analysis show the level of student education of the sharia economy has a significant effect compared to other variables on students' interest in saving. But simultaneously, all independent variables influence the interest in saving students in Islamic banking. This shows that education is very important for students, therefore STIE Widya Gama Lumajang should indeed provide quality teaching to students, especially in the field of Islamic economics..
\end{abstract}

Keywords: Disposable Income, Education, Social Environment, Religiosity, Interest in Saving

Cite this as: Murniati, W., Juliasari, D., Hanifah, N. (2020). DETERMINANTS OF INTEREST IN SAVING FOR STUDENTS IN ISLAMIC BANKING. Assets : Jurnal Ilmiah Ilmu Akuntansi, Keuangan dan Pajak, 4(2), 89-100

\section{INTRODUCTION}

Saving money is a positive activity that must be done early. Various benefits provided in this activity, specifically in financial management. Students as part of the community must familiarize themselves with this rescue activity. In addition to providing benefits for themselves, this activity will also benefit the economy of the community. Students tend to have a high consumptive nature, so saving is not a top priority in their financial arrangements. Today, saving is very easy with the development of various media saving. Banks are one of the savings media that are considered effective, both conventional or Islamic banks.

Nowday, Islamic finance is built on the basis of Islamic religious philosophy with the principle of justice. Therefore, the practice of Islamic economics must be far from riba which is the excess 
collected with the amount of debt that contains elements of persecution and oppression, not just excess or additional money. Riba is known as a term that is closely related to economic activity. The prohibition of riba is one of the main pillars of Islamic economics, besides the implementation of zakat and the prohibition of maisir, gharar and vanity matters (Murniati, 2018).

The concept of Islamic sharia based finance has grown into a trend in the world, including in Indonesia. Based on sharia banking data, the growth of conventional banks is smaller than sharia banks where sharia banks have experienced a relative growth of around $40 \%$ per year in the last ten years while conventional banks have only 20\% in Indonesia (Direktorat Perbankan Syariah, 2011). It is possible that the growth of Islamic banking will exceed conventional systems as well. Indonesian Sharia Finance Development Roadmap state that development of Islamic finance has produced various achievements, from the increasing number of products and services, to the development of infrastructure that supports Islamic finance. Even in the global market, Indonesia is among the top ten countries that have the largest Islamic financial index in the world. However, the growth of Islamic finance has not been able to offset the growth of conventional finance. This can be seen from the market share of Islamic finance which is still below 5\% overall. However, when viewed from each type of sharia products, up to the end of December 2016, there were a number of sharia products whose market share was above $5 \%$, including sharia banking assets of $5.33 \%$ of all banking assets, state sukuk which reached $14.82 \%$ of total outstanding state securities, sharia financing institutions at $7.24 \%$ of total financing, special sharia financial services institutions at $9.93 \%$, and sharia microfinance institutions at $22.26 \%$. Meanwhile, sharia products whose market share is still below 5\%, including outstanding corporate sukuk of $3.99 \%$ of the total value of sukuk and corporate bonds, net asset value of sharia mutual funds by $4.40 \%$ of the total value of the net assets of mutual funds funds and sharia insurance by $3.44 \%$. In addition to the above financial products, shares of listed companies and public companies that meet the criteria for sharia shares reached $55.13 \%$ of the stock market capitalization listed on the Indonesia Stock Exchange. The figures above show that Indonesia's Islamic finance still needs to be developed so that it can offset the growth of conventional finance in order to grow the financial industry as a whole (Otoritas Jasa Keuangan, 2018)

The development process of sharia economy in Indonesia is inseparable from the development of banking for sure. Banking is everything related to banks, covering institutions, business activities and ways of carrying out their business activities. The main function of Indonesian banking is as a collector and distributor of public funds and aims to support the implementation of national development in order to improve the distribution of development and its results, economic growth and national stability, towards improving the lives of many people (Fajar Mujaddid, 2019; Otoritas Jasa Keuangan, 2016). Indonesia itself is a developing country, has a very rapid banking development. This can be seen both in bank office facilities and all banking products offered to the public, conventional and sharia. An Islamic bank is a financial institution that carries out an intermediary function in collecting public funds and channeling financing to the public in accordance with sharia principles This makes various Islamic banking products run on a system far from riba. This is one of the things that has an effect on increasing interest in using Islamic banking products in the community, as well as among students.

Students who are part of the community will always be part of the development of banking in the community, conventional and also sharia. Various banking products have been used by students to fulfill their needs, as well as deposit. Therefore, this research assumes about students deposit interest in Islamic banking related to education, social environment, religiosity and their disposable income for sure. Education is assumed to have an influence on students' interest in saving on Islamic banking because the basic activity of students is learning. Therefore knowledge is very close to them. This is supported by the research of Fajar Mujaddid, et al (2019) entitled Influence of Knowledge, Reputation, Environment and Religiosity on the Interest of Vocational High School Students in Sharia Banking Study Program in Saving in Islamic Banks using banking study program students as research objects. Using multiple linear regression analysis shows that 
the variables of education, reputation, environment, and religiosity can explain the saving interest variable of $51.9 \%$ (Fajar Mujaddid, 2019). The next variable, is considered to be very close to students, is social environment and religiosity. These two variables consist of several interrelated indicators. The social environment is a place of student interaction, then the indicator for this variable is the environment of parents, schools and society in general. The same thing happen for variable religiosity, indicators are given because this variable must be assessed from several points of view. For students themselves, religiosity has been inherent since they were born. But of course religiosity is not only assessed by this matter, every act after giving religion is also a consideration in measuring this variable. The last variable is disposable income, which be interpreted with student income. This income comes from various source like their parent or maybe job.

STIE Widya Gama Lumajang is one of university in Lumajang, East Java. Development of sharia economic, made this university have to develop the education curriculum as needed. STIE Widya Gama Lumajang made some curriculum adjustments by adding several courses in accordance with the concept of sharia economics. This step is considered to be done because students must always obtain updated knowledge about their background study. It will be influence the education of student as well. Therefore, population of this research is student of Accounting of STIE Widya Gama Lumajang.This study was conducted to determine the effect of disposable income, knowledge, social environment and religiosity on saving interest in Islamic banks for students. These variables are considered the most basic factor in determining students' interest in saving at a Sharia Bank. Furthermore, the results obtained are expected to contribute positively to the development of studies on sharia investment and provide a more insight to the reader regarding sharia investment. In addition, the results of this study are expected to reduce community involvement in the practice of riba and improve the development of Islamic economics in Indonesia

In general, Islamic banks are established with the intention to develop the application of Islamic principles in each of their transactions, the next question is how students respond to the existence of Islamic banking and whether they are interested in practicing Islamic concepts or not. In general, for students, there are several factors that can influence interest in saving in Islamic banking. One of them is disposable income which is a fundamental factor in the saving process, as well as in students. The greater the income earned by students in each period of time, the greater the possibility of saving processes.

If you look at the curriculum at the STIE Accounting Study Program Widya Gama Lumajang already has a course that explains the concept of sharia economics. This should be enough to encourage students to carry out economic activities in Islamic banking, especially in terms of saving in Islamic banking. But in reality the interest in saving students, especially in the Accounting Study Program, is still very low.

Another fundamental factor in students' interest in saving in Islamic banking, is the social environment of students. Students in general are in several social environments, including homes, schools or colleges and society in general. Therefore, the social environment variables in this study use several dimensions. Besides the factor of religiosity (religion) with the aim of avoiding riba is a driving factor for saving decisions. On the research (Fajar Mujaddid, 2019; Musruroh, 2015; Ramadhani, Susyanti, \& ABS, 2019), states that religiosity has a significant effect on the variable interest in saving. This is different from the results of the study (Hatmawan \& Widiasmara, 2017) where religiosity does not have a significant influence on saving interest.

From the factors presented and the results of previous studies which stated inconsistencies in the results of research related to the interest in saving, it made the need for re-testing of students, especially STIE Accounting Study Program Widya Gama Lumajang. Therefore, the following hypothesis is used in this study, among others; 
H1. The disposable income has a significant effect on students' interest in saving

H2. Education has a significant effect on students' interest in saving

H3. Social environment has a significant effect on students' interest in saving

H4. Religiosity has a significant effect on students' interest in saving

\section{METHODS}

This research is quantitative research with a survey approach then this research does not make changes or there is no special treatment of the variables studied. The purpose of this research is explanatory where is a type of research that explains the causal relationship between one variable with other variables through hypothesis testing (Setyobakti, 2018)

The object of this study is the students of Accounting Study Program STIE Widya Gama Lumajang with a total of 1080 active students in the academic year 2019/2020. Sampling was carried out using the purposive method aside with the criteria being (a) active students and (b) taking Islamic economics courses. Then obtained a number of students 39 respondents with a research instrument in the form of a questionnaire containing statements related to the variables used in this study. The variables in this study include disposable income $\left(x_{1}\right)$ the education variable $\left(x_{2}\right)$, social environment variable $\left(x_{3}\right)$, religiosity variable $\left(x_{4}\right)$ as independent variables, while the variable of student interest in saving $(y)$ is the dependent variable.

Determinant in deposit interest is influenced by many things from the consumer side. If in the context of students, the independent variables in this study are assumed to represent these determinants. The education variable in this study is in accordance with the definition of consumer knowledge which is stated with everything that is known and understood by consumers about a product being marketed and is inherent and can influence consumer behavior in buying. Therefore through the support of available information can also encourage someone to make a decision including the purchase (Fajar Mujaddid, 2019).

Whereas for social environment variables, Dewantara (2010:212) stated that the social environment can be divided into three places, namely the family environment, school environment and community environment (Yuliyatun, 2012). Furthermore, the social environment indicators outlined, among others, from the family environment include the way parents educate and the atmosphere of the home, from the school environment to include the relationship between teacher and teacher and student relations with students, from the social environment including forms of community life and associating friends. The same thing applies to the variable religiosity where there are several indicators applied to this variable. Broadly speaking, religiosity includes three things are beliefs (aqeedah), norms or law (sharia) and behavior (morals). Religiosity is the level of belief, trust, and piety in a person undergoing religious law which is manifested in various aspects of life including economic aspects (Suwarsi \& Putri Wulandari, 2018). While the disposable income variable in this study is as income that is ready to be used to buy consumer goods and services and the rest is savings that is channeled into investment (Musruroh, 2015).

The first stages of the analysis process are testing research instruments using validity and reliability tests. Validity is the accuracy of an instrument in measurement. Testing the validity of the data used in this study, used data processing through SPSS (Statistical Product and Service Solutions) using the product moment correlation formula. While the reliability measurement method used is the Alpha Cronbach $(\alpha)$ method. Cronbach's Alpha coefficient indicates the extent of the consistency of respondents in answering the instrument being assessed. Reliability test is done by looking at the Cronbach Alpha coefficient (Tavakol \& Dennick, 2011), as follows: 
Table 1. Reliability Criteria Index

\begin{tabular}{ccc}
\hline No. & Alpha Cronbach & Reliability \\
\hline 1. & $0,5>\alpha$ & Unacceptable \\
\hline 2. & $0,6>\alpha \geq 0,5$ & Poor \\
\hline 3. & $0,7>\alpha \geq 0,6$ & Questionable \\
\hline 4. & $0,8>\alpha \geq 0,7$ & Acceptable \\
\hline 5. & $0,9>\alpha \geq 0,8$ & Good \\
\hline 6. & $\alpha \geq 0,9$ & Excellent
\end{tabular}

Source: statisticshowto.com

Then multiple linear regression analysis is performed with the classic assumption test which includes testing data normality, multicollinearity and heteroscedasticity. Mulitiple linear regression is method which used to get the effect of independent variables on the dependent variable. In general, multiple linear regression equations are given as follows; $y=a+b_{1} x_{1}+b_{2} x_{2}+b_{3} x_{3}+\cdots+b_{n} x_{n}$

The model of multiple linear regression will be good if it qualify the classical assumptions. In general there are fthree classical assumption tests on this model. The normality test is carried out with a view to knowing whether the model residues are normally distributed or not. This test use Kolmogorov-Smirnov test. Then for multicollinearity shows that linear relationship between some or all variables explaining the regression model or between one independent variable and another independent variable in a linear correlated linear regression model. If there is relatively perfect multicollinearity, the estimator through the least square or OLS (Ordinary Least Square) becomes erratic and the variance and standard deviation become undefined. When the Variance Inflation Factor value below 10 is mean that the data free from multicollinearity. The last test is heterokedastisitas means that the variable variance is not the same for all observations. Means heterokedastisitas is a condition where the data contains cross section data elements and has different variance. To find out whether the data used in the regression model meets the assumption that heterokedasticity does not occur is to look on scatterplot, if the data distribution values are not clear and the points spread above and below the number 0 on the $\mathrm{Y}$ axis, then not heterokedastisitas occur.

The next step is hypothesis tes for partially and simultaneously for each variable. Partially test is t tes which is one of the statistical tests used to test the truth or falseness of the null hypothesis which states that between the two sample means taken randomly from the same population, there is no significant difference (Sudijono, 2011). While the $\mathrm{f}$ test is used to test all independent variables on the dependent variable in this study.

\section{RESULTS AND DISCUSSION}

The case study of this study was conducted at STIE Widya Gama Lumajang, so the respondents of this study were STIE Widya Gama Lumajang students. There are several criteria that must be qualify to become respondents in this study, one of which is for the variable of knowledge, the class of students who meet are those who have taken courses related to Islamic economics. Therefore final semester students are an appropriate criterion for this study.

This research was conducted on accounting students of STIE Widya Gama Lumajang with a total of 1080 active students per 2019/2020 academic year. Sampling was conducted using a purposive method aside with criteria for students who have received courses in Islamic economics with a total of 216 active students. Furthermore, 39 respondents were used as samples in this study. Each respondent took notes related to a questionnaire that had been given previously related to the variables in this study. 
Table 2. Descriptions of Respondents by Gender

\begin{tabular}{clccc}
\hline No. & & Gender & Total & \% \\
\hline 1. & Male & 14 & $35,9 \%$ \\
\hline 2. & Famale & 25 & $64,1 \%$ \\
\hline Total & & 39 & $100 \%$ \\
\hline
\end{tabular}

Source : result of study questionnaire

Table 3. Descriptions of Respondents by Age

\begin{tabular}{cccc}
\hline No. & Age Interval (year old) & Total & \% \\
\hline 1. & $21-30$ & 38 & $97,4 \%$ \\
\hline 2. & $31-40$ & 1 & $2,6 \%$ \\
\hline 3. & $41-50$ & 0 & $0 \%$ \\
\hline Total & & 39 & $100 \%$ \\
\hline
\end{tabular}

Source : result of study questionnaire

Table 2 shows that the sample in this study was dominated by female respondents with $64.1 \%$ and the remaining 35.9\% are male. While based on age, STIE Widya Gama Lumajang is one of the tertiary institutions which does not provide a maximum age limit for its students. Therefore, the age interval of STIE students Widya Gama Lumjang student is quite diverse. Table 3 show that most of the age of the sample lies at intervals of 21-30 years and only $2.6 \%$ have an age above 31 years.

Disposable income $\left(x_{1}\right)$ is the amount available for households to spend or save (Dornbusch \& Fischer, 1997). This variable is considered as the main determining factor in individual consumptive activities, such as saving. Variable $x_{1}$ in this study has a maximum value of Rp. $3,000,000$ while a minimum of Rp. 100,000. This is a fairly wide data interval considering that respondents are students of STIE Widya Gama Lumajang. The reason is because STIE Widya Gama Lumajang has a class intended for students who are already working. While the average of this variable is Rp.697,435.90 which means that most of the amount of money spent by respondents per month is around Rp.600,000 for all their needs.

Responses related to the education variable $\left(x_{2}\right)$ in this study, the total score of respondents' answers about the questionnaire is 1408 . While the maximum score on the questionnaire of this variable was 1950 obtained from multiplication calculations between 5 as a score maximum, 39 as the number of respondents and 10 which is the number of items used in this questionnaire. So we get a temporary conclusion that the level of agreement of respondents about $\left(x_{2}\right)$ is $(1408 / 1950) \times 100 \%=72.21 \%$. Its means that $72,21 \%$ of respondents agreed with each statement of this variable.

Varible $\left(x_{7}\right)$ in this study has 3 indicators, that the researcher assumes that the social environment of students is family, school and community environment. This takes into account the scope of the socialization that is in students. For family indicator, the total score of respondents' answers about the questionnaire for this variable is 1350 . While the maximum score on the questionnaire of this variable is 1365 obtained from multiplication calculations between 5 as the maximum score, 39 as the number of respondents and 7 which is the number of items used in this questionnaire. So we get a temporary conclusion that the level of agreement of respondents about this variable is (1350/1365) $\mathrm{x}$ $100 \%=98.90 \%$. Its means that $98.90 \%$. of respondents agreed with each statement of this variable. Then for school indicator, as a whole it can be seen that the total score of respondents' answers about the questionnaire for this variable is 1263 . While the maximum score on this variable questionnaire is 1560 obtained from the multiplication calculation between 5 as a maximum score, 39 as the number of respondents and 8 which is the number of items used in this questionnaire. So we get a temporary 
conclusion that the level of agreement of respondents about this variable is $(1263 / 1560) \times 100 \%=$ $80.96 \%$. Its means that $80.96 \%$. of respondents agreed with each statement of this variable. And then for community indicator, total score of respondents' answers about the questionnaire for this variable is 972. While the maximum score on this variable questionnaire is 1170 obtained from the multiplication calculation between 5 as the maximum score, 39 as the number of respondents and 6 which is the number of items used in this questionnaire. So we get a temporary conclusion that the level of agreement of respondents about this variable is $(972 / 1170) \times 100 \%=83.07 \%$. Its means that $83.07 \%$. of respondents agreed with each statement of this variable.

Variable $\left(x_{4}\right)$ has several indicators, including beliefs (aqeedah), religious practices (worship) and practice (morals). Aqeedah indicator have total score of respondents' answers is 1810. While the maximum score on the questionnaire of this variable is 1950 obtained from multiplication calculations between 5 as the maximum score, 64 as the number of respondents and 10 which is the number of items used. So we get a temporary conclusion that the level of agreement of respondents about this variable is $(1810 / 1950) \times 100 \%=92.82 \%$. The for religious practice, total score of respondents' answers is 1708 . While the maximum score on this variable questionnaire is 1950 obtained from multiplication calculations between 5 as the maximum score, 39 as the number of respondents and 10 which is the number of items used. So we get a temporary conclusion that the level of agreement of respondents about this variable is $(1708 / 1950) \times 100 \%=87.58 \%$. And then for moral indicator, total score of respondents' answers is 1694 . While the maximum score on the questionnaire of this variable is 1950 obtained from multiplication calculations between 5 as the maximum score, 39 as the number of respondents and 10 which is the number of items used. So we get a temporary conclusion that the level of agreement of respondents about this variable is $(1708 / 1950) \times 100 \%=86.87 \%$. Its means for beliefs (aqeedah), religious practices (worship) and practice (morals), the value of agreement respondents is $92.82 \%, 87.58 \%$ and $86.87 \%$.

The results of respondents 'responses related to variable $Y$ can be seen that the total score of respondents' answers about the questionnaire for this variable amounted to 1338. While the maximum score on this variable questionnaire was 1950 obtained from multiplication calculations between 5 as the maximum score, 39 as the number of respondents and 10 were is the number of items used in this questionnaire. So we get a temporary conclusion that the level of agreement of respondents about this variable is $(1338 / 1950) \times 100 \%=68.6 \%$. This agreement value kind a lower than other variable in this study.

The results of validity test in this study indicate that all items of statement on each variable have $r$ count $>0.3$ with a significant level of under $5 \%$. it can be concluded that the questionnaire used to extract data is valid so that it can dig up data or information required. Then for reliability test, is carried out to measure the extent to which the questionnaire submitted can give results that are not different using the Cronbach Alpha formula. Obtained test results for each variable as follows:

Table 4. Reliability Test Result

\begin{tabular}{lcl}
\hline \multicolumn{1}{c}{ Variable } & Cronbach's Alpha & Reliability \\
\hline Education $\left(x_{2}\right)$ & 0,775 & Acceptable \\
\hline Social Enviroment $\left(x_{3}\right)$ & 0,769 & Acceptable \\
\hline Religiosity $\left(x_{4}\right)$ & 0,763 & Acceptable \\
\hline Student Interest In Saving $(Y)$ & 0,787 & Acceptable \\
\hline
\end{tabular}

Source : results of questionnaire data processing with SPSS

The reliability test results indicate that all variables are acceptable which is shown in the results of Cronbach's Alpha > 0.7. So it can be concluded that all measuring concepts of each variable from the questionnaire used in this study are reliable questionnaires. 
After testing the quality of the questionnaire, the next step of analysis process is multiple linear regressiona. The regression equation model that can be written from these results in the form of unstandardized coefficients regression equations are as follows: $y=-6,154-(2,150 e-6) x_{1}+1,009 x_{2}+0,122 x_{3}-0,039 x_{4}$

The linear relationship between variables can be seen from the regression equation. A relationship is said to be or positive if the change in the independent variable will affect the dependent variable with positive way. It means that if there is an increase of independent variable then the dependent variable will experience the same thing. This is different from the negative relationship, where an increase in the independent variable will cause a decrease in the dependent variable. From the results of the regression equation above, we get the interpretation that $x_{1}$ and $x_{4}$ give a negative relationship to the variable $Y$. This is different from other variables, where $x_{2}$ and $x_{9}$ have the positive effect relationship with $y$.

The coefficient $x_{1}$ is $-(2,342 e-6)$ shows that the alteration of $x_{1}$ will affect the variable $y$ by $2,342 e-6$ with a negative relationship while it is assumed that other independent variables are also constant. This relationship is also owned by the variable $x_{4}$ with a variable coefficient of -0.039 . This shows that the alteration of $x_{4}$ it will affect the value of $y$ by 0.039 while it is assumed the other independent variables are constant. Furthermore, for other variables $x_{2}$ and $x_{\mathrm{g}}$, the coefficient of the variables is 1.009 and 0.122 . This shows that there is a positive relationship between the independent and dependent variables, assuming the other independent variables are constant.

Tabel 5. Multicollinearity Test Results

\begin{tabular}{cccl}
\hline Variable & Tollerance & VIF & \multicolumn{1}{c}{ Result } \\
\hline$x_{1}$ & 0,739 & 1,353 & Free of Multicollinearity \\
\hline$x_{2}$ & 0,698 & 1,433 & Free of Multicollinearity \\
\hline$x_{3}$ & 0,254 & 3,933 & Free of Multicollinearity \\
\hline$x_{4}$ & 0,277 & 3,615 & Free of Multicollinearity \\
\hline
\end{tabular}

Source : output of SPSS

The results of testing the classic assumptions in the regression model of this study indicate that regression model qualify the classical assumption test requirements. The normality test with Kolmogorov-Smirnov shows Sig $=0.118>\alpha=5 \%$ which means that the residual regression model is normally distributed. Meanwhile, to show multicollinearity symptoms can be seen from the high VIF (Variance Inflation Factor) value in the independent variables of a regression model. VIF values greater than 10 indicate the presence of multicollinearity symptoms in the regression model (Sugiyono, 2015). The test results shown in collinearity statistics to look for VIF values are presented as follows:

The multicollinearity test results show that all variables used as predictors of the regression model show a fairly small VIF value, where all of them are under 10 and the tollerance value is more than 0.1 . This means that the independent variables used in the study do not show the presence of multicollinearity symptoms, which means that all the independent variables in this study are mutually independent variables. 


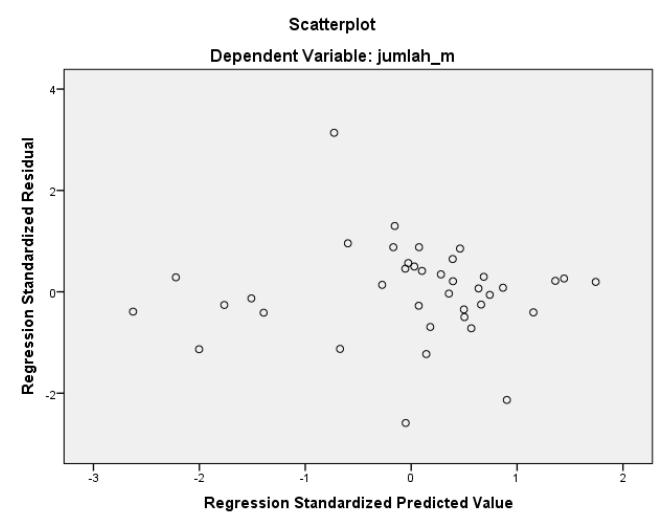

Figure 1. Scatter Plot

Source: output SPSS

Heteroscedasticity test is done using Scatter Plot. If there are no significant variables, it can be concluded that there is no heteroscedasticity problem. The test results are given in Figure 1. Heteroscedasticity test results show there is no clear pattern of these points. This shows that the regression model has no symptoms of heteroscedasticity, which means that there is no significant interference in this regression model.

Table 6. t Test Result

\begin{tabular}{ccc}
\hline Variable & $\mathbf{t}$ & Sig. \\
\hline$x_{1}$ & -.900 & .375 \\
$x_{2}$ & 5.463 & .000 \\
$x_{3}$ & 1.005 & .322 \\
$x_{4}$ & -.466 & .644 \\
\hline
\end{tabular}

Source : output of SPSS

After analyzing multiple linear regression equations, hypothesis testing is performed to test the hypothesis of this study. Based on Table 6 it is known that not all the independent variables of this study have a partial effect on the $y$ variable. Here only $x_{2}$ has a significant influence on the $y$ variable by $\mathrm{Sig}=0,000<5 \%$. This shows that student knowledge is very important in terms of saving interest in Islamic banking. In contrast to the simultaneous hypothesis test, where Sig. = 0.000 where all independent variables can influence the dependent variable together. This is reinforced by the coefficient of determination of $61.2 \%$ which states that the independent variable in this study can explain the dependent variable by $61.2 \%$ and the rest is explained by other independent variables outside this study.

Saving money is putting aside some of the money with intention to keep that money for future needs. Saving money is one way to manage finances to achieve your desires. According to KBBI, saving is derived from the basic word that is tube. Saving means something into a verb group or class so that saving can express an action, existence, experience, or other dynamic understanding. The benefits of saving are many, including (1) saving will teach life to be more efficient and not excessive in spending costs (money) on things that should not be so necessary, (2) train you to be able to live in a more simple or simple way, (3) saving is also a long-term investment that will be very very useful for the future, (4) saving can also teach you to continue to be more patient with difficulty to achieve what you want through a long process, etc. Seeing the many benefits of saving, saving should be taught from an early age. So students are also encouraged to get used to saving. 
Saving can be done in various media. Over time, banking products that can be utilized to meet savings needs are increasingly varied. The public or even students can choose any product that is considered efficient for them, conventional or sharia banking. The development of sharia economics which is rapidly increasing indeed has an influence on the development of sharia banking. People are more likely to choose Islamic banking to meet their savings needs, as well as students. Therefore we need various studies to analyze the determinants of students' interest in saving in Islamic banking so that it can support the development of Islamic economics.

H1. The disposable income has a significant effect on students' interest in saving. The first hypothesis which states that disposable income has a significant effect on the interest of saving students in Islamic banking. Based on the results of the hypothesis test, it is known that disposable income does not have a significant effect on students' interest in saving in Islamic banking. As we know that the amount of disposable income for students is very diverse. This is because there are some students who have worked and some others do not work. For students who are already working, the income earned can be said to be high, in contrast to students who are not working. However, consumption patterns will reflect one's level of expenditure, as well as saving. Keynes states that consumption is influenced by disposable income. The disposable income used for saving is the remaining income because it is not used up for consumption (Dewi, Amar, \& Sofyan, 2013). If the level of student consumption is high, saving is not the first choice in their expenses.

H2. Education has a significant effect on students' interest in saving. Education here is everything that is known and understood by students. In this research, this education is understanding related to basic Islamic banking and the development of sharia economic. Accounting of STIE Widya Gama Lumajang has implemented a curriculum that contains courses on sharia economics so that students can gain their knowledge related to sharia economics from this course. This give a positive influence on saving interest in Islamic banking. In accordance with the results of the partial test for the education variable, that interest in saving students is significantly influenced by student education.

This can be interpreted that the knowledge possessed by students, especially accounting study programs, affects the interest of saving in Islamic banks. Based on the identification of students' knowledge, that the savings system in Islamic banks is fairer because it adopts the Islamic investment system in Islam. These results are in line with research (Mulyaningtyas, Soesatyo, \& Sakti, 2020), which states that the knowledge of Islamic banks affect the interest in saving students.

H3. Social environment has a significant effect on students' interest in saving. It is common knowledge that humans are social creatures. Humans cannot fulfill their needs and desires without interacting with one another. Humans live in the environment. The environment will have an effect, whether strong or not, on the behavior of the individual human (Lailasari, Hufron, \& ABS Khairul, n.d.). But based on the results of hypothesis testing it was concluded that the social environment did not have a significant effect on students' interest in saving.

The results of this study say that the social environment does not have a significant influence on students' interest in saving. This is in line with research (Junaidi, 2015) which states the environment has no effect on the selection of Islamic banks by the public. One of the factors of the lack of interest in saving students is due to a lack of family environment that teaches about the importance of saving, so the habits inherent in students today with a consumptive lifestyle. Likewise in the school environment and society in general. Therefore more consistent actions are needed from both parents and the community to improve savings habits in Islamic banks. 
H4. Religiosity has a significant effect on students' interest in saving. The higher level of one's religiosity will encourage someone to gain knowledge so that the products they use are not prohibited by the religious law they hold. Someone who has high religiosity better understands and is aware of Islamic laws. However, religiosity is not one of the factors that influence people's interest to save at Islamic banks. In addition, the community is more concerned with profit from the sharia element in making transactions which makes religiosity not affect the community's interest in using the services of sharia banks (Saifudin, 2018).

The results of this study indicate that religiosity does not significantly influence the interest in saving students in Islamic banking. When viewed from the background of student religion at STIE Widya Gama, it can be illustrated that even though the majority of Muslims name the knowledge about religion is still lacking. So there are always other factors besides religiosity that can increase students' interest in saving money in Islamic banking. As obtained from the simultaneous test results, it was stated that all independent variables in this study had a significant effect.

\section{CONCLUSION}

The conclusions is knowledge variable significantly influences saving interest in sharia banking, in contrast to other independent variables that do not significantly influence. Simultaneously, the independent variables in this study have a significant influence on students' interest in saving on Islamic banking.

\section{REFERENCES}

Dewi, E., Amar, S., \& Sofyan, E. (2013). ANALISIS PERTUMBUHAN EKONOMI, INVESTASI, DAN KONSUMSI DI INDONESIA. Kajian Ekonomi.

Direktorat Perbankan Syariah. (2011). Outlook Perbankan Syariah Indonesia. Bank Indonesia.

Dornbusch, R., \& Fischer, S. (1997). Ekonomi Makro. Jakarta: Penerbit Erlangga.

Fajar Mujaddid, P. T. A. N. (2019). Pengaruh pengetahuan, reputasi, lingkungan dan religiusitas terhadap minat pelajar Sekolah Menengah Kejuruan prodi perbankan Syariah dalam menabung di bank Syariah. Jurnal Ekonomi Islam, 10(1), 14-37.

Hatmawan, A. A., \& Widiasmara, A. (2017). FAKTOR -FAKTOR YANG MEMPENGARUHI NIAT PADA PERILAKU NASABAH MENABUNG DI PERBANKAN SYARIAH DENGAN AGAMA SEBAGAI VARIABEL KONTROL. Assets: Jurnal Akuntansi Dan Pendidikan. https://doi.org/10.25273/jap.v5i2.1192

Junaidi, J. (2015). Persepsi Masyarakat Untuk Memilih Dan Tidak Memilih Bank Syariah (Studi Kota Palopo). Fokus Bisnis: Media Pengkajian Manajemen Dan Akuntansi, 14(2), 1-13. https://doi.org/10.32639/fokusbisnis.v14i2.44

Lailasari, Hufron, M., \& ABS Khairul, M. (n.d.). ANALISIS PENGARUH FAKTOR LINGKUNGAN EKSTERNAL TERHADAP KEPUTUSAN PEMBELIAN HANDPHONE LAYAR SENTUH MEREK SAMSUNG DI KALANGAN MAHASISWA FE UNISMA. EJurnal Riset Manajemen, 139-151.

Mulyaningtyas, I. F., Soesatyo, Y., \& Sakti, N. C. (2020). PENGARUH PENGETAHUAN TENTANG BANK SYARIAH DAN LITERASI KEUANGAN TERHADAP MINAT MENABUNG SISWA PADA BANK SYARIAH DI KELAS XI IPS MAN 2 KOTA MALANG. JURNAL EKONOMI PENDIDIKAN DAN KEWIRAUSAHAAN. https://doi.org/10.26740/jepk.v8n1.p53-66

Murniati, W. (2018). Penambahan Jumlah Investasi pada Simulasi Perhitungan Profit Model Investasi Syariah Musyarakah. MUST: Journal of Mathematics Education, Science and Technology. https://doi.org/10.30651/must.v3i2.2229

Musruroh, A. (2015). Analisis Pengaruh Tingkat Religiusitas dan Disposible Income Terhadap Minat Menabung Mahasiswa di Perbankan Syariah. Sekolah Tinggi Agama Islam Negeri 
Salatiga.

Otoritas Jasa Keuangan. (2016). Booklet Perbankan Indonesia 2016 Edisi 3.

Otoritas Jasa Keuangan. (2018). Roadmap pengembangan keuangan syariah 2017-2019. In Otoritas Jasa Keuangan.

Ramadhani, N. Ik., Susyanti, J., \& ABS, M. K. (2019). Analisis Pengaruh Tingkat Religiusitas, Pengetahuan dan Lingkungan Sosial Terhadap Minat Menabung Mahasiswa di Bank Syariah Kota Malang. E-Jurnal Riset Manajemen, 79-87. Retrieved from www.fe.unisma.ac.idemail:e.jrm.feunisma@gmail.com

Saifudin, T. (2018). Pengaruh Promosi, Religiusitas, dan Kepercayaan Terhadap Minat Masyarakat Menabung di Bank Syariah dengan Pengetahuan Masyarakat sebagai Variabel Intervening (Studi Kasus Masyarakat Di Kota Salatiga). Salatiga: IAIN Salatiga. SKRIPSI.

Setyobakti, M. H. (2018). Analisis Kinerja Perangkat Desa di Kabupaten Lumajang. Wiga : Jurnal Penelitian Ilmu Ekonomi. https://doi.org/10.30741/wiga.v8i2.316

Sudijono, A. (2011). Pengantar Statistik Pendidikan. In Anas Sudijono. https://doi.org/10.14746/gl.2011.37.3

Sugiyono, P. D. (2015). Statiska untuk Penelitian. In Statiska untuk penelitian.

Suwarsi, A. A., \& Putri Wulandari, N. (2018). IDENTIFIKASI POTENSI NASABAH BARU BANK SYARIAH DITINJAU DARI CUSTOMER SWITCHING INTENTION. Jurnal Ekonomi Dan Bisnis Islam (Journal of Islamic Economics and Business). https://doi.org/10.20473/jebis.v3i2.6808

Tavakol, M., \& Dennick, R. (2011). Making sense of Cronbach's alpha. International Journal of Medical Education, 2, 53-55. https://doi.org/10.5116/ijme.4dfb.8dfd

Yuliyatun. (2012). Pengaruh Lingkungan Sosial dan Motivasi Belajar Terhadap Prestasi Belajar Ekonomi Pada Siswa Kelas VIII MTs AL Irsyad Ngawi Tahun Ajaran 2011/2012. Univesitas Muhammadiyah Surakarta. 